\title{
The Quest for Ethical Teachership as an Embodiment of Professionalism Through Spirituality and Moral Reasoning Among Ghanaian Teachers
}

\author{
Alexander Kyei Edwards, Ed.D \\ Centre for Educational Policy Studies, Institute for Educational Research and Innovations Studies, \\ University of Education, Winneba, GHANA
}

\begin{abstract}
The quest for ethical teachership has led to this investigation purposely to examine the relationship between spirituality and moral reasoning among teachers in Ghana. The issue is the need for ethical leadership within the work of teaching. The study employs an associational design that involved a purposive sample of 156 teachers who were available at a SEIP workshop organized by the Ministry of Education. In all 136 participants responded with usable data from a survey questionnaire which had items on spirituality (SI), moral reasoning (MR), and biographic information. Results showed respondents' levels of SI and MR which were appropriated along the principles of ethical teachership. The correlation between SI and MR was found to be positive $(r=0.27)$. Tests of group differences showed no statistical significance among gender $(\mathrm{t}=1.46, \mathrm{df}=134, \mathrm{p}=0.146)$ but a statistical significance difference among age groups $(\mathrm{F}(4.58), \mathrm{df}=134, \mathrm{p}=0.004)$. Discussions surrounded the purposefulness and moral domain in the work of teaching, a practical interest in authentic learning, and ethical teachership for the success of NTC teacher licensure policy in Ghana. Study recommendations include:(i) such humansitic conceptss are to be taken seriously practice and policy leadership; (ii) ethical teachership can guarantee trusted educational results, and (iii) scholarship must engage on such socio-moral-scientific discussions surrounding ethical issues in educaton. Despite methodological limitations, further research should look at other adulthood concepts within the framework of teachership.
\end{abstract}

Keywords: ethical teachership, Ghana education, moral reasoning, spirituality, teachers

DOI: $10.7176 / \mathrm{JEP} / 10-20-05$

Publication date:July $31^{\text {st }} 2019$

\section{Introduction}

The Ghanaian teacher is central in the national education development (NED) agenda 2030, which is framed with national interests, national relevance, sociocultural values, and human capital growth for the national development. There is a renew call for professionalism and teacher leadership for learning in Ghana (GES/TED Handbook 2014; MoE/SEIP, 2017; The Cambridge Network, 2014). The Cambridge Network summed it up as L4L (Leadership for Learning) grounded in certain domains: moral purpose, democratic values, professional activities, and agency in making learning happen. The new curriculum framework for teacher standards outlined by the United Kingdom's Agency for International Development and Cooperation, which is responsible for the T-TEL (Transforming Teacher Education and Learning) programme in Ghana (T-TEL, 2016), is also intended basically to produce professional teachers with $\mathrm{C} 21$ st skills and competencies for raising professional standards and learning outcomes.

For that matter, there is a quest for teachership, a professional aptness among teachers, which by extension calls for meaningfulness, value creation, and moral obligation to commensurate the work of a 'teacher' in whose hands the education enterprise is committed within the society. Teachership is about the whole idea of teaching, the work of teaching, and the disposition of being a teacher. The concept of teachership is defined as the recognition of professional identity, professional behaviour and attitudes associated with the work of teaching (Ursin and Paloniemi, 2019). Teachership is the ability to influence teaching and learning because of the professional identity attached to a person, which demands a moral disposition, and a meaningful task assignment within the confines of a professional grouping. This is conceptually similar but beyond the idea of teacher leadership espoused by many researchers such as Ann Lieberman and Lynne Miller (2005) who claimed that the teacher is a leader of a sort in the business of education. Hence, according to Jani Ursin and Susanna Paloniemi (2019), teachership is defined as synonymous to the influence exerted by teachers in their professional duties within the school system where the core duty is teaching and learning. According to the authors, teachership is exhibited perhaps through their "personal and emotional meanings of the cultural and social legacies of everyday knowledge" transfer in a given society (p. 4).

In furtherance of identifying teacher leadership (teachership), Jani Ursin and Susanna Paloniemi (2019) confirmed that the concept of teachership involves teaching as an activity, a personal disposition, and a process. Teacher professional identity has gained a significant attention in recent literature partly because teachers are now identified to demonstrate leadership for learning (L4L) in schools (Beijaard, Meijer, and Verloop, 2004, as 
cited in Ursin and Paloniemi, 2019; The Cambridge Network, 2014). Ursin and Paloniemi suggested that "professional identity has four necessary features: (1) it is an on-going process, (2) it implies both a person and a context, (3) it consists of sub-identities, and (4) it contains agency as an important element" (p. 3). But to add to this discourse is to look at The Cambridge Network's (2014) framework for improving teaching and learning that included a moral purpose, democratic values, a focus on learning, and a shared sense of accountability. These are meaningful organization of learning through a charted pathway for leadership with a purposeful and moral values from which the conception of teachership emanated to include not only professional identity but an expansion of the conception of teachership to include the quest for ethical teacher professional influence.

The quest in this context is for teachers to claim ownership of authentic learning results (from their learners), coming from their work as teachers (based on performance indicators), and can be attributed to their ethical professional disposition in exercising their call of duty. If a teacher cannot demonstrate leadership for learning, exhibit ethical teachership, he or she has no business to claim 'ownership' of learning results or having influenced the learning outcome. The proposition here is that teachership should therefore give a new meaning to claims of having influenced students' academic performance in the classroom, in the ecology of the school, and the holistic upbringing of pupils as citizens; the teacher should have the ethical and moral justification for any claim of learning outcomes. That is the cause of ethical teachership. Robert Starratt (1994) saw ethical issues in United Kingdom schools and recommended the building of structures to raise ethics and standards.

Therefore the research is based on teachers' perspective to address the concept of teachership by examining their levels of spirituality as pertaining to meaning in life (or spiritual involvement - SI) and moral reasoning (MR) as in situational judgment. The main intent is to find the nexus between these humanistic values in process of establishing an ethical teachership. Albeit, the study was fundamentally posited to give evidence for concern regarding the conceptualization of ethical teachership by looking at the elements of humanistic values, integrity, and sound judgment; by examining the levels of these two study variables when it comes to the assumption of work of teaching (as a profession) within school systems.

\subsection{Research questions and hypotheses}

This study raised two research questions and attempted to juxtaposition them with alternative hypotheses under the assumption that teacher-respondents already possess (post facto) the professional aptness as qualified teachers.

Research question 1: $\quad$ What are the levels of spirituality (SI) and moral reasoning (MR) of teachers to warrant an ethical teachership?

Research question 2: What are the demographic differences in gender and age groups in terms of the two study variables (SI and MR) among the teachers?

Hypothesis 1: There will be no statistically significant positive association between SI and MR when it comes to the quest for teachership.

Hypothesis 2: There is no significant difference between the gender categories among the teachers in the

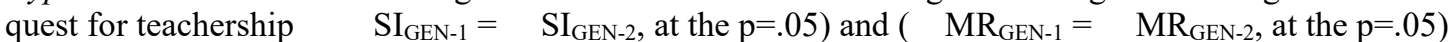

Hypothesis 3: $\quad$ There are no significant differences in the Mean scores for SI and MR within the age groups among the teachers in the quest for teachership. ( $\mathrm{SI}_{\mathrm{AGE}-1}=\mathrm{SI}_{\mathrm{AGE}-2}=\quad \mathrm{SI}_{\mathrm{AGE}-3}=\mathrm{SI}_{\mathrm{AGE}-4}$, at the $\left.\mathrm{p}=.05\right)$ and $\left(\mathrm{MR}_{\mathrm{AGE}-1}=\quad \mathrm{MR}_{\mathrm{AGE}-2}=\quad \mathrm{MR}_{\mathrm{AGE}-3}=\quad \mathrm{MR}_{\mathrm{AGE}-4}\right.$, at the $\left.\mathrm{p}=.05\right)$

\section{Review of related literature}

\subsection{The Work of Teaching in Ghana}

The work of teaching is very important in developing nations. T-TEL programme in Ghana is aimed at transforming the entire teaching profession in Ghana to match the anticipated transformation in the nation's human capital development. Hence according to T-TEL (2016), the Ghana government agenda is looking at teachers as professional citizens who are to raise a new generation of human capital in Ghana capable of transforming the economy. The Ministry of Education in Ghana has established the National Teaching Council (NTC) to back the intervention programme with a national teacher standards framework that focuses on professionalism and sociomoral values (NTC document, 2018). According to the President of the Republic of Ghana, Hon. Nana Addo Danquah Akufo-Addo, who spoke on the national media, saying most successful economies rely on among many other sectors of the economy, the second most important sector is the teacher professionalism to develop their economy (paraphrased). Hence, last year saw the introduction of teacher licensing (NTC document, 2018) which requires all new teachers to pass a compulsory licensure examination to be recognized nationally. Apart from the traditional pedagogical skills requirement, incoming teachers now need to demonstrate affectively values and positive attitudes in the classroom and in examination; they ought to have a purpose-driven curriculum leadership to improve teaching and learning results; and above all, they ought to show integrity, honesty, and trustworthiness as teachers (Hon. Dr. Yaw Adutwum, Deputy Minister speech at the University of Education, Winneba on 3th July, 2019, accessed in the Daily Graphic, on Friday July 5, p. 29). 
In other words, teacher standards are framed with teachers been required to have both pedagogical skills and professionalism, aptitudes, and sociomoral values that will add extra-dimension to value-addedness to their teaching competencies (NTC document, 2018). NTC stresses on teacher identity that focuses on new guidelines to all teacher training institutions (especially, Colleges of Education) in the country. This is a significant change because the work of the teacher is now seen as valuable, intentional, and demanding. The work of teaching has become a complex, intricate, and unnatural undertaking (Ball and Forzani, 2009) for the development of the economy.

First of all, the work of teaching demands a new set of thinking, skills and aptitudes (Edwards and Dampson, 2018). For the C21st Alexander Edwards and Dandy Dampson (2018) recommended a new conceptualized model: Primal Teacher Leadership that are endowed with quadrant intelligences (Qi). Secondly, teaching has assumed a complexity in the sense that "to teach ... is to shift the locus of one's role orientation from the personal to the professional" (Ball and Forzani, 2009, p. 500). Teaching is very intricate because the teacher has to manage a class of about 25 or more, with diverse children, from different backgrounds, different cognitive abilities, and with different attention spans. The work of teaching is so intricate that the teacher is akin to multi-tasking leader at every event daily.

The work of teaching becomes an art, a creative venture, an eventful display of talent and action, which has also becomes an entire project (what Robert Starratt, 1990, termed it as a 'whole drama'), involving actors and directors (and sometimes with ghost actors, the seen and unseen such as parents and supervisors). Deborah L. Ball and Francesca M. Forzani (2009) painted the narrative of the work of teaching very well as an episode of instruction comprises many tasks and moves, many of them invisible to a casual observer.... choose tasks, examples, models or analogies, and materials. [Teachers] manage individual student behavior and maintain a productive learning environment, pose strategically targeted questions, interpret students' work, craft responses, assess, and steer all of this [sip] toward each student's growth. (p. 501)

\subsection{Teachership as a Leadership Concept}

Teachership is a professional identity label on those assigned to be leaders in the act of teaching and learning (Lieberman and Miller, 2005). Teachers are practitioners of multi-leadership in dealing with parents, school administrators, staffs and school management and education authorities (Oduro, 2007, 2009). In Ghana for example, teachers deal with the Ghana Education Services (GES), their corporate objectives, WAEC tests administration, government policies, and community priorities with such a coordination that resonate immerse acumen of professionalism and organizational skill. They demonstrate leadership of a people, with a framework of leader-member relationship (LMX), and they are full of participation with a class of people (Yukl, 2010). A demonstration that is tantamount to influencing the outcome of many proactivity and achievements in the school system. We talking about what Kouzes and Posner (2012) referred to as an exemplary leadership in getting extraordinary results (in this case learning). Jani Ursin and Susanna Paloniemi (2019) also referred to teachership as a professional identification - a professional task or responsibility that connotes one's identity.

Teaching is an activity that engages all actors in a given scenery for creating a concerted learning outcomes. One has to be identified as such - i.e., these days be certified. The actors include learners (pupils) themselves, parents and guardians, school leadership and authorities, school administrative staffs and workers, and all associated stakeholders. The teacher is identified as a central figure in the ecology of the school and an educator (Leithwood, Louis, Anderson, and Wahlstrom, 2004). His/her activity involves a deliberate influence of the transmission of knowledge, broadening of the learning horizons, deepening of insights, and stimulating thought and feelings. In conjunction, the teacher transmits social norms, values, and culture. The work of teaching becomes an activity that involves the influences and processing of social norms, cultural values, domestic and geographical dispositions, religious, social and political contexts (Aggarwal, 2004).

In this act, the teacher is a practicing leader-i.e., practitioner in the art of influencing teaching and learning in a social context - the school environ. Teaching engages the personal disposition where individual philosophy of life, values and purpose are displayed; it is a socio-moral appropriation of awareness, knowledge and skills; and it becomes a contagious vicious cycle of knowledge creation, training of minds, and scaffolding learning behaviours (Heil, 2004; Vygotsky, 1978). John Heil (2004) said the teacher concerns itself with the "ontology of mind" that "revolves around reflections on questions about mind that fall partly or wholly outside the purview of the sciences" (p. 5). Beyond which teachership tends in this context to connote far more than (i) personal identification with the professional practices, (ii) pedagogical skills of teaching activities, (iii) instillation of standards, expectations, and value addedness to society (Edwards, 2015; Ursin and Paloniemi, 2019). As a call of duty, teachership assumes an ethical dimension and the juxtaposition of personal versus social interests. The teacher's role as an educator transcend beyond creating avenues for the acquisition of knowledge and wisdom; the teacher inculcates moral and spiritual values, and acts as parent to develop children physically, morally, and spiritually. 
There is a multi-dimensionality to the concept of teachership. It is more than a professional identity. It is profoundly seen and reflected in the teacher acting as the mother, the father, the counselor, the comforter, the all-knowledgeable-go-to person. The Teacher is the driver/leader in the early stages of our childhood development. And it becomes a vocation, a personal disposition of transference of a meaning-making venture.

\subsection{The Teacher as a Moral Agent}

Teachership has a socio-moral and 'spiritual' dimensions (Aggarwal, 2004). Teachership involves personal values, beliefs, and moralization. Aggarwal (2004) explained that education involves both physical and spiritual activities. Under the spiritual activities the teacher encounters the intellectual, moral, aesthetic and religious developments. These serve to bring a complete and ideal education (or what some text prefer to term as a "holistic education') of a child. The teacher is in the middle of this very important adventure in the society. He/she has to have the spirituality and morality context to command the moral agency. He or she has to be the person in the arena to command ethical teachership in a socio-cultural context and in practical content delivery. The teacher's command of the belief in the supernatural endowment of higher powers and values may serve as the guarantee for spirituality engagement (Delgado, 2005) and a moral barometer (Starratt, 1994).

Furthermore, teachership is an intentional and authenticated process that serve as the agency for integrity, honesty and trustworthiness. Researchers agree that by examining the process of getting the intended teaching and learning results, pedagogically, cognitively, and reflectively, a wide range of the art of teachership exercised by teachers becomes originality of a process, a methodology, and a pedagogical competency that tend to authenticate a claim of ownership of learning outcomes (Ball and Forzani, 2018; Casalaspi, Hutt, and Schneider, 2018; Ursin and Paloniemi, 2019). In other words, if teachers do everything ethically their results can be authentic and professionally vindicated (Casalaspi et al. 2018). It is in this light of thinking that teachers are expected to engage in training that involves ethical pedagogical processes of instruction. Learning how to teach, teacher training, becomes the pre-process of raising teachership, a moral agent - i.e., a deliberate process with a proven systematic performance technology, a predisposition of psychological mind process (Heil, 2007), and a sociological process of producing ethical teachership (Casalaspi, et al., 2018). Casalaspi, et al. (2018) opined that for good teachers, their moral uprightness and trustworthiness with academic results are critical. The teacher is the pinnacle of any socio-moral knowledge base. They serve as the know-how knowledge is acquired, how education is achieved, and how competencies are transferred or gained. They are all about a systematic shift to leading a meaningful learning. Teachership as a moral agency that commands the processes and procedures that are ethical and believable (Starratt, 1991; 1994).

\subsection{Spirituality and Moral Reasoning in Ethical Teachership}

However, many researchers are engaged with the issue as to whether spirituality involvement (SI) and moral reasoning (MR) can contribute significantly to the quest for ethical teachership, which is a professional expediency among teachers. For instance, spirituality accounts for meaningfulness in life (Drath and Palus, 1994; Fry, 2000), the belief in existentialism (citing Canda's theory of existentialism by Delgado, 2005) that makes "meaning of things and events moment-by- moments" (Delgado, 2005, p. 159). Spirituality gives a purposedriven life to human activities in education (Edwards, 2015). Spirituality is perceived as having the capacity to connect to a supernatural power (Burkhardt and Nagai-Jacobson, 2002), the interconnection to powers beyond oneself in any human endeavour (Delgado, 2005). Spirituality is therefore expressed by purpose-driven thoughts and deeds that guarantee integrity, authenticity and responsibilities. Unlike religiosity, spirituality involves internalization, intuition, and existentialisms of beliefs (Bhindi and Duignan, 1991; Delgado, 2005; Edwards, 2015). Religiosity may be the ritualization; spirituality is more of internalization (Tirri, Tallent-Runnels, and Nokelainen, 2005).

For morality, the teacher is supposed to lead in a sociomoral judgment and quest for decency, trumpeting values and giving sound judgment that is both believable and behaviourally sensible. Moral reasoning on the other hand is defined as the ability to make sensible judgment on issues or situations regardless of sentimentalities (Rest, 1980). This is emanating from moralization where the individual is developed to have sensitivity, sensibility, the values and preferences for others (Lovett and Jordon, 2010). But moral reasoning converged at a specific point where the individual show reasoning-ability based on a sound judgment regarding a situation or a circumstance (Loviscky, Trevion, and Jacobs, 2007). Thus, many researchers (Rest, Narvaez, Babeau, and Thoma, 1999; Starratt, 1991; 1994) are always asking whether modern teachers have the sociomoral judgment to possibly account for the enormous trust assigned to them by society (a whole nation's citizenry human capital development in teachers' hand). Again, many of these researchers are still asking: teachers undertake such a magnitude of responsibility in the national education enterprise and shouldn't they be ethically accountable? Teachers should be examined on the grounds of reasoning-ability and trustworthiness before such a responsibility.

Against the issue of spirituality and morality is raised the question of ethical teachership. Is the society right in their request for ethical teachership, professionalism, and the vocationalization of the teaching profession? To 
be ethical in all decisions one has to have the moral purpose, the reasoning ability, and standards (Shapiro and Stefkovich, 2001). According to Shapiro and Stefkovich, ethical decisions are good reflection of one's moral grounds. Globally, we have several instances of situations whereby the integrity of professional teachers are questioned. In Ghana, we have instances where teachers are involved in questionable characters; sexual abuses, examination malpractices, and unethical relationships and dispositions that tend to place a dent on the teaching profession (Ghanaweb, 2018; Edwards and Entsuah, 2019). The concept of moralization (the level of moral reasoning) always raises fundamental issues of teachers as custodians of moral values in the learning processes. There are questions lingering on the caliber of teachers, their responsibility for contributing to authenticity of academic results, and leading to several investigations on teachers' motives for career choices as teachers (IERIS Study, unpublished, 2017). However, the question is on the entrusted teachers with the professional aptitudes to 'teach'. A recent study by Edwards and Entsuah (2019) found that examination mal-practices happen because teachers are culprits in students cheating. Students believe the teachers are helpful in cheating. In the Brong Ahafo region, for example, the study found that students may request help from teachers during examination because the students know that teachers will offer the help (Ghanaweb, BA-examination-malpractices, 2016). According to such evidence, most teachers do not have the strong purpose and moral etiquette needed to avoid the temptation of helping students to cheat- a significant quest for ethical teachership.

\section{Method}

\subsection{Research design and Sample and Procedures}

The research design is correlational focused on post facto levels of the study variables (SI and MR) and therefore the design is to ask questions with predetermined sample to describe an existing situation in an attempt to establish a significance association between the study variables (Fraenkel and Wallen, 2006). This design was appropriate because of the self-reporting nature of what already exist as teachers' levels of spirituality, moral reasoning, and their disposition towards professionalism as in the context of ethical teachership. Participants $(\mathrm{N}=156)$ were purposively sampled from a Secondary Education Improvement Project (SEIP) workshop. These were participants who are teachers and heads of schools who were undergoing training and development on the concept of Leadership for Learning (L4L) (an aspect of leadership aimed at improving results in failing schools developed by the Cambridge Network, UK). SEIP workshops were organized by the Ministry of Education/Ghana Education Services under the sponsorship of the Ghana government/World Bank (SEIP, 2017).

The participants are similar in characteristics and they are practicing teacher professionals. The accessible population were all informed teacher and school leaders participating in various sessions of training in management, leadership (L4L), and pedagogical skills. Their purposeful inclusion to participate in this study was primarily based on SEIP school membership, attending the training/workshop sessions, and happened to be available for data gathering during one of the sessions. By implication the SEIP was to inculcate teachership for effective teaching and learning. The sessions were therefore focusing on the role of teachers in L4L, providing inspiration for L4L, and placing emphasis, ethically, on the shared accountability for results in learning.

\subsection{Data Measurements, Collection, and Analyses}

Data for SI was from Spirituality Involvement and Beliefs scale - revised version (SIBS-R) published by (Hatch, Naberhaus, Helmich and Burg, 1998) with 22 items on a 5-point Likert scale (i.e., 5=strongly agree, 4=Agree, $3=$ Neutral, $2=$ Disagree, $1=$ Strongly disagree). The SIBS-R has an internal consistency (Cronbach's alpha of 0.92) and a 50-50 split in reliability test (Hatch et al, 1998). The MR data came from analysis of responses from two scenarios based on typical moral dilemmas in the course of teaching. The scenarios were (i) professional negligence in script marking, and (ii) teacher absenteeism. There were question items on What should or should not be done followed to analyse judgment on moral decisions. Then there are Simple Sum Scores (SSS) of by a 12 itemized questions. Similarly, the 12 items had 5-point Likert scale (i.e., 5=great, 4=much, 3=somehow, $2=$ little, $1=$ none).

The entire data collection instrument was one survey questionnaire constructed by combining SIBS-R, the two MR scenarios (fashioned after similar studies such as Rest et al., 1988; Edwards and Entsuah, 2019; Loviscky, Trevion, and Jacobs, 2007), and demographic information section. The survey questionnaire was to last between 30 to 40 minutes. Data were cleaned, transformed and analysed into Spirituality (SI) and moral reasoning (MR or SSS) scores. Further statistical tests (independent sample t-test and ANOVA) were conducted to test the alternative hypotheses on the means scores with a statistical significance at a probability $(\mathrm{p}=.05)$.

\subsection{Results and Discussions}

\subsection{Demographic results}

The first results of interest was the demographic characteristics of the respondents (Table 1). The response rate was $87.18 \%$. ( $n=136$ respondents provided usable data). Demographically, Table 1 shows diverse teacher respondents dominated by the middle-age group (56.0\% are $30-40$ years) and hence can be said to have reached 
their career consolidation stage of adulthood (Bee and Bjorklund, 2006). There are majority claiming themselves to be spiritual $(52.9 \%)$, morally upright $(83.8 \%)$ as teachers. But data from spirituality and moral reasoning contradicted their claims (as seen in subsequent data analysis to answer research questions).

\begin{tabular}{llll} 
Table 1: Demographics Characteristics of Respondents & $(N=136)$ & & \\
\hline Category & Groups & $f$ & 80.9 \\
\hline Gender & Male & 110 & 19.1 \\
\multirow{2}{*}{ Age } & Female & 26 & 9.6 \\
& Below 25 years & 13 & 46.3 \\
& $26-35$ years & 63 & 22.8 \\
Marital status & $36-40$ years & 31 & 21.3 \\
& Above 40 years & 29 & 61.0 \\
& Married & 83 & 32.4 \\
Self consideration-(Spiritual) & Single or not married & 44 & 1.5 \\
& Divorced & 2 & 4.4 \\
\multirow{4}{*}{ Self consideration-(Moral) } & Undeclared & 6 & 52.9 \\
& Yes, spiritual person & 72 & 24.3 \\
& Not Spiritual person & 33 & 22.8 \\
& Undeclared (not sure) & 31 & 83.8 \\
& Yes, moral person & 114 & 0.00 \\
\hline
\end{tabular}

Source: Field data

\subsection{Research questions}

4.2.1. Research questions 1: To what extend do teachers have the levels of meaning in life (SI) and moral reasoning (MR) to warrant an ethical teachership?

This question was answered by looking at the Mean scores of SI and MR (plus their sub components (Table 2). It is followed by a further look at judgmental actions scores in the two moral dilemmas (indicated by 'Should or Should not', Table 3).

Table 2: Levels of Spirituality and Moral Reasoning $\quad(N=136)$

\begin{tabular}{llllll}
\hline Variable & Sub-Variable & Min. & Max. & Mean & Std. Dev. \\
\hline Spirituality & Meaning in Life (SI) & 51 & 99 & 78.46 & 7.79 \\
Morality Aggregate & Mean of Means & 23.67 & 55.67 & 37.73 & 5.49 \\
Moral Scenario \#1 & Moral Reasoning (MR)-SSS & 20 & 56 & 38.68 & 5.63 \\
Moral Scenario \#2 & Moral Reasoning (MR)-SSS & 21 & 55 & 38.16 & 6.07 \\
\hline
\end{tabular}

Table 3: Level of Reasoning According to Action to be Taken

\begin{tabular}{|c|c|c|c|c|c|c|c|}
\hline \multirow[t]{2}{*}{ Dilemma } & \multirow[t]{2}{*}{ Question } & \multicolumn{2}{|c|}{$\underline{\text { Should }}$} & \multicolumn{2}{|c|}{ Can't decide } & \multicolumn{2}{|c|}{ Should Not } \\
\hline & & $f$ & $\%$ & $f$ & $\%$ & $f$ & $\%$ \\
\hline Scenario \#1 & $\begin{array}{l}\text { Should Mike raise this issue for discussion at } \\
\text { the next staff meeting? }\end{array}$ & 82 & 60.3 & 18 & 13.2 & 36 & 26.5 \\
\hline Scenario \#2 & $\begin{array}{l}\text { Should the Head master reprimand Alex at } \\
\text { the next staff meeting? }\end{array}$ & 56 & 41.2 & 33 & 24.2 & 47 & 34.6 \\
\hline Both \#1\&\#2 & Aggregate decisions & 69 & 50.75 & 25.5 & 18.7 & 41.5 & 30.55 \\
\hline
\end{tabular}

Again, table 2 indicated that Spirituality (SI) had a Mean score of 34.78, with SD =7.79. The Mean of means for Moral Reasoning (MR) is also 37.73 with $\mathrm{SD}=5.59$. The sub-variables in terms of the two moral scenarios recorded average scores (e.g., $\mathrm{SSS} \# 1$, Mean $=38.68, \mathrm{SD}=5.63$ ).

With regard to MR by reason of judgment, table 3 showed that majority respondents $(60.3 \%)$ are ready to raise the moral issue for discussion at next staff meeting. But when it came to reprimanding a colleague (Alex) for absenteeism and lying about it, a smaller number of teacher respondents (41.2\%) want to reprimand Alex for wrong doing. The aggregate decision for such a tough decision was at a mid-point (50.75\%) - a moderate level. Only 69 out of 136 wanted to do something about the issues of moral reasoning by way of judgment and action.

On the question of levels of SI and MR, which is spirituality and moral reasoning respectively, Table 3 indicates SI (Mean=78.76, $\mathrm{SD}=7.79)$ and $\mathrm{MR}($ Mean $=38.16, \mathrm{SD}=5.49)$ which are moderate by way of comparison.

4.2.2. Research question 2: Are there demographic differences in gender and age groups in terms of the two study variables (SI and MR) among the teachers?

First, the independent sample t-test for the gender groups was analysed against the two study variables, SI and MR. Table 4 showed SI $(\mathrm{t}=1.46, \mathrm{df}=134, \mathrm{p}=.146>0.05)$ and $\mathrm{MR}(\mathrm{t}=-0.37, \mathrm{df}=134, \mathrm{p}=0.712>0.05)$. 
Table 4: Differences Between Gender Groups regarding Spirituality and Moral Reasoning (T-Test)

\begin{tabular}{cccccccc}
\hline & Gender & $n$ & Mean & Std. Dev. & $t$ & $d f$ & Sig. \\
\hline Spirituality (SI) & Male & 110 & 78.94 & 7.13 & 1.46 & 134 & 0.146 \\
& Female & 26 & 76.46 & 10.07 & & & \\
Moral Reasoning (MR) & Male & 110 & 112.94 & 16.8 & -0.37 & 134 & 0.712 \\
& Female & 26 & 114.27 & 15.22 & & & \\
Moral Scenario \#1 & Male & 110 & 38.47 & 5.66 & -0.87 & 134 & 0.387 \\
& Female & 26 & 39.54 & 5.53 & & & \\
Moral Scenario \#2 & Male & 110 & 37.96 & 6.27 & -0.78 & 134 & 0.436 \\
& Female & 26 & 39.00 & 5.15 & & & \\
\hline
\end{tabular}

Table 5: ANOVA Descriptive Statistics for the Age Group and Study Variables

\begin{tabular}{|c|c|c|c|c|c|c|c|c|c|}
\hline & Age & $n$ & $\begin{array}{l}\text { Sum of } \\
\text { Squares }\end{array}$ & SD & $\begin{array}{c}\text { Std } \\
\text { Error }\end{array}$ & $\begin{array}{l}\frac{95 \% \text { CI for }}{\underline{\text { Means }}} \\
\text { Lower Bound }\end{array}$ & $\frac{95 \% \text { CI for }}{\text { Means }}$ & Min & $\operatorname{Max}$ \\
\hline \multirow[t]{5}{*}{ Spirituality (SI) } & 1 & 13 & 73.38 & 6.65 & 1.46 & 69.36 & 77.40 & 63.00 & 83.00 \\
\hline & 2 & 63 & 79.14 & 7.90 & & 77.15 & 81.13 & 51.00 & 97.00 \\
\hline & 3 & 31 & 76.35 & 6.87 & & 73.84 & 78.87 & 61.00 & 89.00 \\
\hline & 4 & 29 & 81.52 & 7.60 & & 78.83 & 84.40 & 68.00 & 99.00 \\
\hline & Total & 136 & 78.46 & 7.79 & .67 & 77.14 & 79.79 & 51.00 & 99.00 \\
\hline \multirow{5}{*}{$\begin{array}{l}\text { Moral Reasoning } \\
\text { (MR) }\end{array}$} & 1 & 13 & 108.54 & 16.8 & 2.41 & 103.28 & 113.80 & 100.00 & 126.00 \\
\hline & 2 & 63 & 114.60 & 15.22 & 2.37 & 109.87 & 119.33 & 71.00 & 163.00 \\
\hline & 3 & 31 & 110.52 & & 1.95 & 106.54 & 114.49 & 91.00 & 130.00 \\
\hline & 4 & 29 & 115.07 & & 3.43 & 108.04 & 122.10 & 90.00 & 167.00 \\
\hline & Total & 136 & 113.19 & 16.47 & 1.41 & 110.40 & 115.98 & 71.00 & 167.00 \\
\hline
\end{tabular}

The Levene's test of equality of variances was also conducted within the ANOVA and it indicated homogeneity within the age groups (see Table 6).

Table 6: Test of Homogeneity of Variances

\begin{tabular}{lllll}
\hline Variable & Levene's Statistics & df1 & df2 & Sig \\
\hline Spirituality (SI) & .25 & 3 & 132 & 0.86 \\
Moral Reasoning (MR) & 3.49 & 3 & 132 & 0.02 \\
\hline
\end{tabular}

4.3. Results on the hypotheses

4.3.1Hypothesis 1: There will be no statistically significant positive association between SI and MR.

This was tested with Pearson $r$ at $\mathrm{p}=0.5$ for significance, According to Table 8, the hypothesis is rejected ( $\mathrm{r}=.27$, $\mathrm{p}=.002$ ). Professional issues such as the one raised in the study scenarios may be far-fetched because of certain extraneous factors beyond the scope of this present study. However, the discussion is still varied that levels of spirituality involvements and moral reasoning are strong variables to inform ethical behaviours among respondents. Especially when table 8 shows that both variables correlated positively $(\mathrm{r}=0.27, \mathrm{p}=0.002)$.

4.3.2Hypothesis 2: There is no significant difference between the gender categories among the teachers in the quest for teachership. This was tested with independent sample t-test and the results showed that the hypothesis was not rejected because of SI $(\mathrm{t}=1.46, d f=134, \mathrm{p}=0.146>0.05)$ and MR $(\mathrm{t}=-0.37, d f=134, \mathrm{p}=0.712>0.05)$.

4.3.3Hypothesis 3: There are no significant differences in the Mean scores for SI and MR within the age groups among the teachers in the quest for teachership. This was tested with a one-way ANOVA and the results showed that the hypothesis is not rejected for $\mathrm{SI}(\mathrm{F}=4.98, d f=134, \mathrm{p}=0.004)$ but rejected for $\mathrm{MR}(\mathrm{F}=0.90, d f=134, \mathrm{p}=0.445)$ (with reference to table 7).

\subsection{Further discussions}

Even though findings conforms with that of Edwards and Aboagye (2015) with the evidence of no statistical significance differences among the gender and age categories when it comes spirituality, in the case of moral reasoning there is enough evidence in research to prove that such humanistic values develop with age, maturation in social cultural and time contexts. According to adulthood texts, faith-development, or meaning in life, tends to be a significant indicator of maturity (Bee and Bjorklund, 2006). Just as moralization increases with age (Lovett and Jordon, 2010) so is wisdom, knowledge, and understanding stemming from maturation and sensitivity to socio-moral experiences. The statistical differences may not be significant, and alternative hypotheses may be rejected because of the homogeneity of the sample (see Levene's test of homogeneity in table 
6), yet the fact still remains that differences (otherness) exist in sameness (Edwards, 2014). Characteristically, these are trained teachers with technical and professional sameness; they are socio-culturally aligned with similarities in their natural differences (Edwards, 2015; Edwards and Aboagye, 2015). Yet, this sameness is interwoven with disparity and disagreements echoed by several studies on the subject of spirituality and morality (Gilligan, 1988; Kohlberg, 1984; Rest et al., 1986) when it comes to natural tendencies and differences in gender and age categories.

Finally, nonetheless, the findings reiterated various studies that showed significant relationship between spirituality and morality in any professional setting (especially in most studies within the health sector, see Delgado, 2005). Therefore these concepts shown in the trajectories of adulthood have their place and interdependency evidently in research (Jacob, 2018; Lovett and Jordon, 2010). Their relationship must of necessity be taken as a positive correlation $(\mathrm{r}=.27)$ warranted for ethical teachership development. The relationship between purposefulness (spirituality) and good judgment (MR) is conceptually important in the quest for high level performance and integrity in teachership. The significant locus of control in this case stems from the fact that teachers relate with learners (students), parents, staffs, colleagues as part of their daily routine in activities, processes, and responsibilities (Ball and Forzani, 2019). Influence of these teachers can therefore be either positive or negative depending on their levels of personal spirituality involvement and moral reasoning (which according to the data are at moderate levels). By examining the nexus between these subjects in terms of correlation is a contribution to shaping the understanding of the phenomenon of teachership ethically. The quest for ethical teachership is illuminated by this purposeful and socio-moral relationship between spirituality and moral reasoning. The evidence suggests such a positive inclination, statistical significance or otherwise.

\subsection{Conclusion, recommendations, and limitations}

\subsection{Conclusion}

The quest for ethical teachership is an advancement of the work and conception of teacher leadership in general that focuses more on professional identity. Ethically, there is an ample evidence of teaching and learning gaining a socio-moral dimension (GES/TED Handbook, 2014). The Cambridge Network (2014) places a premium on the moral dimension in leadership for learning to curtail school/or students' failures in Ghanaian secondary schools (SEIP/MoE, 2017). GES has shown concerns about teachers' morals and their shared values and responsibilities. The study data showed the teachers assumed moderate levels rather than the highest levels of spirituality (SI) (Mean $=78.76, \mathrm{SD}=5.59)$ and moral reasoning $(\mathrm{MR})(\mathrm{Mean}=38.16, \mathrm{SD}=5.49)$ which do not affect their professional identity, work ethics and other activities (Ball and Forzani, 2017), but their perceptions of ethical behaviour, civility in standards, and professional decision making may be compromised or affected by situations (Ellin, 1988; Shapiro and Stefkovich, 2001).

Also, the fact that there are no significant differences in demographic groups indicates the levels of accountability irrespective. The positive correlation results $(\mathrm{r}=0.27)$ indicates the importance well-wishers attach to developing both of these humanistic values among teachers. Casalaspi and colleagues (2018) espoused the value of good teachers, experts not faked ones, in creating values, visions, and passion through meaningful teaching and learning. Researchers mostly call for higher levels of spirituality and moral judgment in order to fulfill a certain level of teacher influence or teachership in schools. The results echo this sentiments that the higher scores of spirituality, the higher moral reasoning one expects to demonstrate as teachers.

Next, the evidence of positive relationship between spirituality and moral reasoning also re-emphasizes the need to have teacher education examine some of these contents along as literature on teachership is fast developing. It is to be given the needed attention in teacher education and adult development. Education relies on 'real' learning results and it is undermined by unethical behaviours particularly from teachers. Especially when in Ghana students cheat in examinations are rampant just so that children can make the grades (Edwards and Entsuah, 2019; Ghanaweb, 2018). Results show that there is no difference between gender groups, male or female, all teachers have to demonstrate ethical concerns.

Hence, professionals may raise well-meaning quests for ethical teachers who are prepared vocationally, psychologically, philosophically, and pedagogically to meet the expectations of the Ghanaian society. As far as education is concern, ethical teachership will naturally impart sociocultural values, meaning making, and moral and professional standards. Conceptually, ethical teachership is an identity, a significant indicator for strategic recruitment and retention of teachers as professionals in Ghana. Teacher development contents must be evaluated to ensure a clear understanding of this phenomenon right at the pre-service teacher training stage. Ghana's educational reforms are only attainable if success can be derived from effective teaching and learning, ethical teachership, and other issues with professionalism such as absenteeism are addressed seriously.

\subsection{Recommendations}

The following recommendations emerged from the study for consideration:

First, the Ghana Education Service (GES) should encourage the development of these two humanistic 
concepts: spirituality and morality within the framework of teacher continuous professional development. These will serve as valuable impetuses for teacher professionalism because they will affect the teachers' vision, values, and moral relevance.

Second, education systems should inspire trainee-teachers to reach the highest levels of spirituality (meaningfulness) and moral reasoning. As adults teachers, as a matter of necessity, should attach significant importance to events and training that develop them spiritually and morally as catalyst to reach the highest levels of ethical lifestyle. Education systems globally should re-examine content priorities. The need for ethical teachership should outweigh the traditional emphasis on pedagogical skills by teacher education institutions. It is about time these institutions develop curricula that are complete balancing act of teaching practices and sociomoral values addedness to avoid most social vices among teachers and citizenry.

Third, there should be in place an education policy leadership in the areas of meaning making, purposedriven lifestyle, spirituality development, moral reasoning, and ethical dimensions of teacher education from the Ministry of Education and other agencies such as the National Teaching Council (NTC). Our educational delivery and human development agenda in that direction should be matter of concern to well-wishing stakeholders. The ruling government and all its agencies have to facilitate policy driven agenda to encourage high levels of meaning in life (spirituality) and sound judgment (moral reasoning) to avoid unethical teacher behaviours. Such policy instruments or leadership should come from the Ministry of Education to the government agencies as a matter of urgency to curtail abuses, corruption, misappropriation and other vices being perpetuated by educators themselves. Ethical discussions should be incorporated in the certification examination content areas. Policy agencies should contextualize spirituality and morality in both pre-service and post-service teacher development texts.

Fourth, the NTC should be well resourced to professionalize the work of teachers to act as socio-moral agents and in consonance with social norms and expectations. Best practices should be discussed at every opportunity. NTC should organize ethical workshop to discuss moral issues, practice circuit-based case studies groups to train teachers in specific areas of ethical teachership concerns. It may call for teachers to volunteer as "Ethical Teachership Watchdog", well-funded and nationally established to add to the quest agency. And as a motivation, this should form part of the teaching practice, part of teacher CPD, and part of additional credits for a career progression. NTC should refrain from shying away in discussing such humanistic values because of contentions because spirituality and morality are core elements of citizenship and professional aptness and should therefore be prioritized in all teacher licensure tests and professional content development.

Finally, the country as a whole should reflect and improve on how we train and encourage faith development, religion, spirituality, and moral education. The fact that the colonial masters' curricula did not courage religious and moral education (RME) should not marginalize such content areas during secondary and tertiary levels. At this level of corruption in the nation, marginalization of RME is affecting ethical leadership, socio-moralization, and unfortunately permeating to teachership. RME at basic level and not fully integrated at other levels is unfortunate. This is because teachers are running low on the levels of spirituality and moral reasoning even though they are supposed to be the custodians of such humanistic values. Teacher education institutions should provide leadership in such a valuable content areas to augment ethical teachership for dealing with national issues and teacher professionalism.

\subsection{Study Limitations}

Study limitations were based on method: i.e., research design, appropriation of ethical dilemmas as scenarios, and data integrity itself. First, the research design focused on quantitative method of assessing spirituality and moral reasoning from teachers who perhaps are not comfortable in giving authentic information about such sensitive subjects. Already research shows that such humanistic concepts attract personal feelings and the ethics of conscience. Secondly, for this study the sample of two scenarios used can best be discussed at the group level, forums, with qualitative observations, and a face-to-face for participants to establish their own 'constructs'. Thirdly, teachers are notorious in giving responses to surveys based on "what they want others to hear". This can affect data integrity. The setting at the SEIP workshop may also contribute to ignite 'quick-fixed' answers in avoidance of any potential ramifications against GES ethical standards. In other words, teacher respondents may like to show professionalism, as in 'looking good factor', rather than talking realities on the ground. Data integrity is still challenging; authenticity of data still depended on trustworthiness of respondents.

However, the study is well intended to examine the concept of teachership in line with the merits of moral and spiritual domains of the work of teaching. A further study suggestion is to examine teachership along the lines of various adulthood trajectories, dispositions such as occupational stress levels, resiliency, generativity, and the influence of such developmental areas on teacher career consolidation. In furtherance, a national debate on faith development, tantamount to spirituality and religiosity, is an important hallmark in adulthood maturity and should be delved into for emphasis on teachership in the education delivery. 


\subsection{References}

Aggarwal, J.C. (2002). Theory and Principles of Education; Philosophies and Sociological bases of education (12th ed.). Delhi: Hindustan Offset Printers.

Ball, D. L. \& Forzani, F. M. (2009). The work of teaching and the challenge for teacher education. Journal of Teacher Education. 60(5), 497-511

Bee, H. L., \& Bjorklund, B. R. (2004). The journey of adulthood (5th ed.). Upper Saddle River, NJ: Pearson Prentice Hall.

Beijaard, D., P. C. Meijer, and N. Verloop. 2004. "Reconsidering Research on Teachers' Professional Identity." Teaching and Teacher Education. 20 (2): 107-128. doi:10.1016/j.tate.2003.07.001.

Bhindi, N., \& Duignan, P. (1997). Leadership for a new century. Educational management \& Administration, 25(2), 117-132.

Burkhardt, M. A., \& Nagai-Jacobson, M. G. (2002). Spirituality: Living our connectedness. Albany, NY: Delmar Thomson Learning.

Casalaspi, D., Hutt, E., \& Schneider, J. (2018). Identifying good teachers: Expert versus ordinary knowledge. International Journal of Education Policy \& Leadership. 13(4) 2018, 1-24

Delgado, C. (2005). A discussion of the concept of spirituality. Nursing Science Quarterly, 18(2), 157-162

Drath, W. H., \& Palus, C. J. (1994). Making common sense: Leadership as meaning-making in a community of practice. Greensboro, NC: Center for Creative Leadership.

Edwards, A.K. (2015). Otherness Development Model for Assessing Multicultural Competencies for Educational Leadership. International Leadership Journal. Winter 2015 Vol. 7, (No. 1). 23-34

Edwards, A.K. \& Dampson, D. G. (2018). Considering Primal Teacher Leadership Through Quadrant Intelligent (Qi) Model for Teacher Education Content Validity In Ghana. International Journal of Education, Learning and Development Vol.6, No.7, pp.94-110

Edwards, A. K. \& Entsuah, S. (2019) Moral Reasoning and Cheating in Examination among Secondary Students in Ghana. International Journal of Innovative Research and Development DOI No.: 10.24940/ijird/2019/ v8/i4/APR19028 Page 144

Fraenkel, J. R., \& Wallen, N. E. (2006). How to design and evaluate research in education (6th edition). New York: McGraw-Hill.

Fry, P. S. (2000). Religious involvement, spirituality and personal meaning for life: Existential predictors of psychological wellbeing in community-residing and institutional care elders. Aging \& Mental Health, 4(4), 375-387.

GES/TED Handbook (2014). Leadership for change: A Handbook for GES management staff. Accra, Ghana: GES/Teacher Education Division/ UNICEF

Gilligan, C. (1987). Moral orientation and moral development. In E. F. Kittay \& D. T. Meyers (Eds.), Women and moral theory (pp. 19-33). Totawa, NJ: Rowman \& Littlefield Publishers

Hatch R.L, Naberhaus D.S, Helmich L.K, Burg, M.A. (1998). Spiritual Involvement and Beliefs Scale: Development and Testing of a New Instrument. Journal of Family Practice, 1998 (46). 476-486.

Heil, J. (2004). Philosophy of Mind: A contemporary introduction ( $2^{\text {nd }}$ Ed). New York, NY: Routledge.

IERIS Study, (unpublished, 2017), Motives for pursuing teaching as a profession by student-teachers in the University of Education, Winneba $(U E W)$. Study Report Unpublished. University of Education, Winneba: Winneba-Ghana.

Jorgensen, G. (2006). Kohlberg and Gilligan: Duet or duel? Journal of Moral Education, 35(2), 179-196.

Kohlberg, L. (1984). The psychology of moral development: The nature and validity of moral stages (Vol. II). San Francisco, CA: Harper \& Row

Kohlberg, L. (1975). Moral education for society in moral transition. Educational Leadership, Oct. 1975, 46-54.

Kohlberg, L., \& Hersh, R. H. (1977). Moral development: A review of the theory. Theory into Practice, XVI (2), 53-59.

Kouzes, J. M., \& Posner, B. Z. (2012). The leadership challenge (4 ${ }^{\text {th }}$ ed.). San Francisco, CA: Jossey-Bass.

Leithwood, K.; Louis, K. S.; Anderson, S. \& Wahlstrom, K, (2004). Review of Research: How leadership influences student learning. University of Minnesota, US: Centre for Applied Research and Educational Improvement

Lieberman, A. \& Miller, L. (2005) Teachers as Leaders, The Educational Forum, 69:2, 151-162, DOI: $10.1080 / 00131720508984679$

Loevinger, J. (1986). On Kohlberg's contributions to ego development. In S. Modgil and C. Modgil (Eds.), Lawrence Kohlberg: Consensus and controversy (pp. 183-193). Philadelphia,PA: The Falmer Press

Lovett, B. J. and Jordon, A. H. (2010), Levels of moralisation: a new conception of moral sensitivity. Journal of Moral Education Vol. 39, No. 2, pp. 175-189. DOI: 10.1080/03057241003754914.

Loviscky, G. E., Trevino, L. K., \& Jacobs, R. R. (2007). Assessing managers' ethical decision making: An objective measure of managerial moral judgment. Journal of Business Ethics, 73, 263-285. 
Oduro, G. K. T. (2009). The missing ingredient: Head teachers Leadership Development in Sub Saharan Africa. Commonwealth Educational Partnership.

Oduro, G. K. T. (2007). Coping with the challenge of quality basic education: the missing ingredient. In D.E.K. Amenumey, (ed.) (2007). Challenges of Education in Ghana in the 21st Century. Accra: Woeli Publishers.

Rest, J. R. (1980). Moral judgment research and the cognitive-developmental approach to moral education. Personnel and Guidance Journal (May 1980), pp. 602-605.

Rest, J. R. (1986). Summary. In J. R. Rest (Ed.), Moral development: Advances in research and theory (pp. 176182). New York: Praeger.

Rest, J. R., Bebeau, M., \& Volker, J. (1986). An overview of the psychology of morality. In J. R. Rest (Ed.), Moral development: Advances in research and theory (pp. 1-27). New York: Praeger.

Rest, J. R., Narvaez, D., Babeau, M., \& Thoma, S. (1999). A neo-Kohlbergian approach: The DIT and schema theory. Educational Psychology Review, 11(4), 291-324.

SEIP/MoE (2017). Secondary Education Improvement Project in Ghana. World Bank sponsored project in Ghana. Unpublished report. Accra, Ghana: Ministry of Education

Shapiro, J. P., \& Stefkovich, J. A. (2001). Ethical leadership and decision making in education: Applying theoretical perspectives to complex dilemmas. Mahwah, NJ: Lawrence Erlbaum Associates.

Starratt, R. J. (1994). Building an ethical school: A practical response to the moral crisis in schools. London, UK: The Falmer Press.

Starratt, R. J. (1991). Building ethical school: A theory for practice in educational leadership. Educational Administration Quarterly, 27(2), 185-202.

Starratt, R. J. (1990). The drama of schooling / The schooling drama. London, UK: The Falmer Press.

T-TEL (2016). The Transforming Teacher Education and Learning programme in Ghana. Theme 6: national Teachers' Standards and Teacher Education Curriculum framework (Professional development Guide for Tutors). Accra, Ghana: Ministry of Education. Retrieved on June 20th 2017 at http://www.t-tel.org.

The Cambridge Network (2014). Leadership for Learning. Retrieved on June 20th, 2018 from https://www.educ.cam.ac.uk/centres/lfl

Tirri, K., Tallent-Runnels, M. K., and Nokelainen, P. (2005). A cross-cultural study of preadolescents' moral, religious and spiritual questions. British Journal of Religious Education, 27(3), 207-214.

Ursin, J. \& Paloniemi, S. (2019): Conceptions of teachership in the professional identity construction of adult educator graduates, Teacher Development, DOI: 10.1080/13664530.2019.1575274

Vygotsky, L. S. (1978). Mind in society: The development of higher psychological processes. Cambridge: Harvard University Press.

Yukl, G. (2010). Leadership in organisations. ( $7^{\text {th }}$ Ed.) New Jersey: Pearson Education Inc. 